\title{
Inhibition of Neointimal Proliferation in Rabbits after Vascular Injury by a Single Treatment with a Protein Adduct of Nitric Oxide
}

David S. Marks, ${ }^{\star}$ Joseph A. Vita, ${ }^{\ddagger}$ John D. Folts, ${ }^{\$}$ John F. Keaney, Jr., ${ }^{\ddagger}$ George N. Welch, ${ }^{\ddagger}$ and Joseph Loscalzo ${ }^{\ddagger}$

*Department of Medicine, Cardiovascular Division, Brigham and Women's Hospital, Harvard Medical School, Boston, Massachusetts 02115; ${ }^{\ddagger}$ Whitaker Cardiovascular Institute, Evans Memorial Department of Medicine, Boston University Medical Center, Boston, Massachusetts 02118; and ${ }^{\S}$ University of Wisconsin Department of Medicine, Cardiology Section, Madison, Wisconsin 53706

\begin{abstract}
Endothelium-derived relaxing factor is important for vascular homeostasis and possesses qualities that may modulate vascular injury, including vasodilation, platelet inhibition, and inhibition of smooth muscle proliferation. $S$-nitrososerum albumin is a naturally occurring adduct of nitric oxide (NO) with a prolonged biologic half-life and is a potent vasodilator and platelet inhibitor. Given the avidity of serum albumin for subendothelial matrix and the antiproliferative effects of NO, we investigated the effects of locally delivered $S$-nitroso-bovine serum albumin $(S$-NO-BSA ) and a polythiolated form of bovine serum albumin ( $\mathrm{pS}$-BSA) modified to carry several S-nitrosothiol groups (pS-NOBSA ) on neointimal responses in an animal model of vascular injury.

Locally delivered $S$-NO-BSA bound preferentially to denuded rabbit femoral vessels producing a 26 -fold increase in local concentration compared with uninjured vessels $(P$ $=0.029)$. p $S$-NO-BSA significantly reduced the intimal $/ \mathrm{me}$ dial ratio $(P=0.038)$ and did so in conjunction with elevations in platelet $(P<0.001)$ and vascular cGMP content $(P \leq 0.001)$. pS -NO-BSA treatment also inhibited platelet deposition $(P=0.031)$ after denuding injury. Comparison of BSA, $S$-NO-BSA, $S S$-NO-BSA, and control revealed a dose-response relationship between the amount of displaceable NO delivered and the extent of inhibition of neointimal proliferation at 2 wk $(P \leq 0.001)$.

Local administration of a stable protein $S$-nitrosothiol inhibits intimal proliferation and platelet deposition after vascular arterial balloon injury. This strategy for the local delivery of a long-lived NO adduct has potential for preventing restenosis after angioplasty. (J. Clin. Invest. 1995. 96:2630-2638.) Key words: endothelium-derived relaxing factor • sulf hydryl groups • vascular smooth muscle cell • cell proliferation
\end{abstract}

A preliminary report of a portion of this work has been presented in abstract form at the National American Heart Association meeting in Atlanta on 11-14 November 1994 and was published in abstract form (1994. Circulation. 90:I-198a).

Address correspondence to Joseph Loscalzo, MD, PhD, Boston University Medical Center, Section of Cardiology, 88 E. Newton Street, Boston, MA 02118. Phone: 617-638-8706; FAX: 617-638-4066.

Received for publication 10 January 1995 and accepted in revised form 11 August 1995.

J. Clin. Invest.

(C) The American Society for Clinical Investigation, Inc.

0021-9738/95/12/2630/09 \$2.00

Volume 96, December 1995, 2630-2638

\section{Introduction}

The vascular endothelium participates in many homeostatic mechanisms important for the regulation of vascular tone and the prevention of thrombosis. A primary mediator of these functions is endothelium-derived relaxing factor (EDRF). ${ }^{1}$ First described in 1980 by Furchgott and Zawadzki (1), EDRF is either nitric oxide (2) (NO) or a closely related NO-containing molecule (3-5).

Removal of the endothelium is a potent stimulus for neointimal proliferation and represents an important mechanism for restenosis of atherosclerotic vessels after balloon angioplasty $(6,7)$. NO dilates blood vessels $(8)$, inhibits platelet activation (9), and limits the proliferation of vascular smooth muscle cells (VSMC) in vitro (10). Similarly, in animal models, suppression of platelet-derived mitogens decreases intimal proliferation (7). The potential importance of endothelium-derived NO in the control of arterial remodeling after injury is further supported by recent preliminary reports in humans suggesting that systemic NO donors reduce angiographic restenosis 6 mo after balloon angioplasty (11).

Biologic thiols react readily with $\mathrm{NO}$ (probably as $\mathrm{N}_{2} \mathrm{O}_{3}$ or $\mathrm{NO}^{+}$) under physiologic conditions to form stable, biologically active $S$-nitrosothiol species $(10,12) . S$-nitrosothiols exhibit EDRF-like activity in vitro and in vivo, including vasodilation (3) and platelet inhibition via a cyclic 3',5'-guanosine monophosphate (cGMP)-dependent mechanism (13-15).

Balloon arterial injury results in endothelial denudation and subsequent regrowth of dysfunctional endothelium (16) that may contribute to the local smooth muscle cell proliferation and extracellular matrix production underlying restenosis of the arterial lumen. We hypothesized that local delivery of an EDRFlike species to restore or replace the relative deficiency of EDRF observed with dysfunctional endothelium will modulate the effects of vascular injury and potentially reduce intimal proliferation after injury. We, therefore, synthesized a form of serum albumin, a plasma protein avid for subendothelial matrix, specifically designed to carry multiple NO groups, and examined its effect on platelet adhesion and neointimal growth after balloon injury.

\section{Methods}

Materials. Sulfanilamide and $N$-(1-naphthyl)ethylenediamine dihydrochloride were purchased from Aldrich Chemical Co. (Milwaukee, WI).

1. Abbreviations used in this paper: EDRF, endothelium-derived relaxing factor; NO, nitric oxide; PCNA, proliferating cell nuclear antigen; $\mathrm{p} S$-BSA, polythiolated BSA; pS-NO-BSA, polythiolated $S$-nitrosoBSA; $S$-NO-BSA, $S$-nitroso-BSA; SNP, sodium nitroprusside; VSMC, vascular smooth muscle cell. 
Sodium bicarbonate, sodium chloride, sodium phosphate, sodium nitrite, potassium phosphate-monobasic, $40 \%$ formaldehyde solution, and sucrose were purchased from Fisher Scientific (Fairlawn, NJ). Sephadex G-25 was purchased from Pharmacia Fine Chemicals (Piscataway, NJ). IODO-BEADS were purchased from Pierce Chemical Co. (Rockford, IL), and $\mathrm{Na}\left[{ }^{125} \mathrm{I}\right]$ from New England Nuclear/DuPont (Boston, MA). [ ${ }^{111}$ In]Oxine was purchased from Amersham (Arlington Heights, IL). Cell culture media (RPMI 1640) and fetal bovine serum were purchased from Gibco Laboratories (Grand Island, NY). Monoclonal mouse antiproliferating cell nuclear antigen (PCNA) antibody was purchased from Dako A/S (Glostrup, Denmark). All other chemicals were purchased from Sigma Chemical Co. (St. Louis, MO).

Citrate-phosphate-dextrose anticoagulant solution contained $10 \mathrm{mM}$ citric acid, $90 \mathrm{mM}$ trisodium citrate, $15 \mathrm{mM} \mathrm{NaH}_{2} \mathrm{PO}_{4}$, and $142 \mathrm{mM}$ dextrose, $\mathrm{pH}$ 7.35. Tris-buffered saline (TBS) consisted of $10 \mathrm{mM}$ Tris, $\mathrm{pH} 7.4$, and $150 \mathrm{mM} \mathrm{NaCl}$. Acid-citrate-dextrose contained $100 \mathrm{mM}$ trisodium citrate and $142 \mathrm{mM}$ dextrose, $\mathrm{pH}$ 6.5. Phosphate-buffered saline contained $10 \mathrm{mM}$ sodium phosphate and $150 \mathrm{mM} \mathrm{NaCl}, \mathrm{pH} 7.4$ or 6.8 (in cell migration assays).

Synthesis of $S$-nitroso species. $S$-nitroso-bovine serum albumin ( $S$ NO-BSA) was synthesized as previously described (12). Fatty acidfree bovine serum albumin $(200 \mathrm{mg} / \mathrm{ml})$ was exposed to a $1.4 \mathrm{M}$-fold excess of $\mathrm{NaNO}_{2}$ in $0.5 \mathrm{~N} \mathrm{HCl}$ for $30 \mathrm{~min}$ at room temperature and neutralized with an equal volume of TBS and of $0.5 \mathrm{~N} \mathrm{NaOH}$. Polythiolated bovine serum albumin ( $\mathrm{p} S$-BSA) was prepared after Benesch and Benesch (17). Briefly, essential fatty acid-free bovine serum albumin $(50 \mathrm{mg} / \mathrm{ml})$ was dissolved in water with $\mathrm{N}$-acetyl-homocysteine thiolactone $(35 \mathrm{mM})$ and $0.05 \%$ polyethylenesorbitan monolaurate. Equimolar silver nitrate was slowly added at room temperature over $90 \mathrm{~min}$ at $\mathrm{pH}$ 8.5. Excess thiourea $(70 \mathrm{mM})$ was added and the $\mathrm{pH}$ was lowered to 2.5. Excess silver nitrate was removed by Dowex 50 chromatography with a mobile phase consisting of $1 \mathrm{M}$ thiourea, $\mathrm{pH} 2.5$, and excess thiourea was removed by Sephadex G-25 chromatography. pS-BSA was prepared within $2 \mathrm{~d}$ of nitrosation and stored at $4^{\circ} \mathrm{C}$. Nitrosation of $\mathrm{p} S$ BSA was accomplished using $3.6 \mathrm{mM} \mathrm{NaNO}_{2}$ in $0.5 \mathrm{~N} \mathrm{HCl}$ for $30 \mathrm{~min}$ at room temperature. The solution was adjusted to $\mathrm{pH} 4.0$ with $0.5 \mathrm{~N}$ $\mathrm{NaOH}$ after nitrosation. In platelet binding studies, $0.1 \mathrm{mM}$ EDTA was added to $\mathrm{p} S$-BSA before nitrosation.

The content of $S$-nitrosothiol was determined by the method of Saville (18). Protein concentration was determined using the method of Lowry and colleagues (19).

Preparation of [ [25I]-labeled S-NO-BSA, [25I]-labeled pS-NO$B S A$, and ${ }^{111}$ In]-labeled platelets. BSA or $\mathrm{pS}$-BSA $(0.1 \mathrm{mg} / \mathrm{ml})$ was combined with two IODO-BEADS and $0.1 \mathrm{mCi}$ of $\mathrm{Na}\left[{ }^{125} \mathrm{I}\right]$ (20). The solution was incubated for $45 \mathrm{~min}$ and unincorporated $\mathrm{Na}\left[{ }^{125} \mathrm{I}\right]$ was removed by gel filtration with Sephadex G-25 equilibrated with TBS. [ $\left.{ }^{125} \mathrm{I}\right]$-Labeled S-BSA had a specific activity of $5.7 \times 10^{6} \mathrm{cpm} / \mu \mathrm{g}$ and [ $\left.{ }^{125} \mathrm{I}\right]$-labeled $\mathrm{p} S$-BSA had a specific activity of $18.2 \times 10^{6} \mathrm{cpm} / \mu \mathrm{g}$. Subsequently both molecules were $S$-nitrosated as described for unlabeled $S$-BSA and pS-BSA. $0.5 \mathrm{ml}$ of [ $\left.{ }^{125} \mathrm{I}\right]$-labeled $S$-NO-BSA or polythiolated $S$-nitroso-bovine serum albumin (pS-NO-BSA) with $1 \times 10^{6}$ cpm was administered with saline control on the contralateral vessel. [ ${ }^{111}$ In]-Labeling was performed after the method of Wistow and colleagues (21).

Animal preparation. All animal preparations were performed within the institutional guidelines of the Brockton/West Roxbury Department of Veteran Affairs Medical Center and Boston University Medical Center and were in accordance with the guiding principles of the American Physiological Society. New Zealand White rabbits $(3.5-4.2 \mathrm{~kg}$ ) of either sex were premedicated with $5 \mathrm{mg} / \mathrm{kg}$ intramuscular (i.m.) xylazine hydrochloride (Miles Pharmaceuticals, Shawnee Mission, KS) and $0.1 \mathrm{mg} / \mathrm{kg}$ subcutaneous atropine sulfate (Lyphomed, Inc., Deerfield, IL) $15 \mathrm{~min}$ before the induction of anesthesia. Anesthesia was induced with $40 \mathrm{mg} / \mathrm{kg}$ i.m. ketamine hydrochloride (Fort Dodge Laboratories, Fort Dodge, IA) and $5 \mathrm{mg} / \mathrm{kg}$ i.m. acepromazine maleate (Aveco Co., Inc., Ford Dodge, IA). Additional doses of ketamine hydrochloride were administered as necessary to maintain anesthesia. For survival studies, 100,000 U penicillin G (Apothecon of Bristol-Myers Squibb, Princeton, $\mathrm{NJ}$ ) was administered intramuscularly perioperatively. The skin over the femoral arteries was next infiltrated with $1 \%$ lidocaine (Astra Pharmaceuticals, Inc., Westborough, MA), and the common femoral arteries were exposed from the inguinal ligament to the superficial femoral artery. Arteries were cleared of connective tissue, side branches were ligated, and the superficial femoral artery was suspended with silk ties. A 1.5-2.0-cm length of femoral artery was isolated from the circulation proximally and distally with neurosurgical microaneurysm clips. The superficial femoral artery was cannulated with a $2 \mathrm{~F}$ Fogarty balloon catheter (American Edwards Laboratories, Santa Ana, CA) that was passed into the isolated segment of femoral artery. The balloon was inflated with sufficient air to generate slight resistance and withdrawn three times. A 20-gauge angiocath was then inserted in the arteriotomy, and $1 \mathrm{mg} / \mathrm{ml}$ of $25.8 \mathrm{mg} / \mathrm{ml} \mathrm{pS}$-NO-BSA or $49.2 \mathrm{mg} / \mathrm{ml}$ $S$-NO-BSA was administered over $15 \mathrm{~min}$. The contralateral femoral artery was prepared identically and an appropriate control $(25.8 \mathrm{mg} / \mathrm{ml}$ $\mathrm{p} S$-BSA, $49.2 \mathrm{mg} / \mathrm{ml} \mathrm{BSA}$, or $0.66 \mathrm{mg} / \mathrm{ml}$ sodium nitroprusside [SNP]) was administered. After administration of the agent, the superficial femoral artery was ligated and flow was reestablished. Sham-operated animals underwent surgical exposure and side branch ligation, but no balloon injury was performed or local delivery administered. The area of balloon injury was marked by surgical staples in the adjacent muscle fascia. For chronic studies, the incision was closed with subcuticular absorbable suture and the animals were allowed to recover. For acute studies, blood was allowed to circulate through the treated areas for 15 min before vessel harvest. In some experiments, a distant control vessel, the right carotid artery, was isolated and harvested without any other manipulation.

cGMP analysis. Whole blood was obtained from fasting human volunteers who had not taken any medications in the past $96 \mathrm{~h}$ and platelet-rich plasma was prepared by centrifugation at $120 \mathrm{~g}$. Platelet counts were determined using a Coulter counter (model ZM; Coulter Diagnostics, Hialeah, FL). After balloon injury and treatment with $\mathrm{p} S$ NO-BSA or $\mathrm{p} S$-BSA, arterial segments were harvested and 2-mm segments were incubated with $100 \mu \mathrm{l}$ platelet-rich plasma containing 10 $\mu \mathrm{M}$ isobutylmethylxanthine. After $1 \mathrm{~min}$, an equal volume of ice-cold $10 \%$ trichloroacetic acid was added to each aliquot and the sample was vortexed. Enzyme-linked immunoassay of cGMP was then performed (Cayman Chemical Co., Ann Arbor, MI). Separate 2-mm vessel segments were also assayed for tissue cGMP after treatment with ice-cold $10 \%$ trichloroacetic acid and sonication (Heat Systems Ultrasonics, Inc., Plainview, NY).

Tissue processing and analysis. On the 14th postoperative day, animals were killed with $120 \mathrm{mg} / \mathrm{kg}$ intravenous sodium pentobarbital (Anpro Pharmaceuticals, Arcadia, CA), and the abdominal aorta and inferior vena cava were interrupted by silk ties. A 7F plastic cannula was inserted into the abdominal aorta and the vessels were perfused clear with saline followed by fixation at $100 \mathrm{mmHg}$ pressure with $10 \%$ buffered formalin. The vessels were stored in $10 \%$ buffered formalin and the samples were paraffin-embedded and microtome-sectioned. Six sections were made along the length of each injured segment of vessel and the specimens were stained with Verhoeff 's stain for elastic tissue. The areas within the lumen, internal elastic membrane, and external elastic membrane were measured by a blinded observer using computerized digital planimetry (Zeiss, Oberkochen, Germany).

In a separate set of animals, vessels were perfusion-fixed with $10 \%$ buffered formalin $7 \mathrm{~d}$ after injury and processed for analysis of proliferating cells within $12 \mathrm{~h}$ as described above. Sections were stained for PCNA and adjacent sections were stained with hematoxylin and eosin. Five representative sections from each segment were examined. Total nuclei were counted from the hematoxylin and eosin slides and percent PCNA-positive cells were defined as the number of PCNA-positive nuclei divided by the total nuclei multiplied by 100 .

[ IIII In]-Labeled platelet studies. Animals were prepared and treated with $\mathrm{p} S$-NO-BSA or $\mathrm{p} S$-BSA as described above. $5 \mathrm{~min}$ before the release of the vascular clamps, autologous [ ${ }^{111}$ In]-platelets were infused 
via the femoral vein, and blood was allowed to recirculate for $15 \mathrm{~min}$ before harvest. Platelet adhesion was quantified with a gamma counter (Capintec Instruments, Inc., Pittsburgh, PA) and normalized to tissue wet weight.

VSMC migration assay. Neonatal rat aortic VSMC were isolated and incubated as previously described $(22,23)$. Cells were maintained in RPMI 1640 supplemented with $10 \%$ fetal bovine serum, penicillin $\mathrm{G}$ sodium $(100 \mathrm{U} / \mathrm{ml})$, and streptomycin $(100 \mu \mathrm{g} / \mathrm{ml})$ and incubated at $37^{\circ} \mathrm{C}$ under $5 \% \mathrm{CO}_{2}$ in air. VSMC from the ninth passage were used for cell migration assays. Migration of VSMC was assayed by a modification of Boyden's chamber method using microhemotaxis chambers (Costar Corp., Cambridge, MA) with polycarbonate filters having pores of $5.0 \mu \mathrm{m}$ in diameter $(24,25)$. Cultured VSMC were treated with $0.05 \%$ trypsin and $0.53 \mathrm{mM}$ EDTA, and were suspended at a concentration of $1 \times 10^{6} \mathrm{cells} / \mathrm{ml}$. A 100- $\mu$ l volume suspension of cells was placed in the upper chamber and a 600- $\mu$ l volume of varying concentrations of $\mathrm{p} S$-NO-BSA and $\mathrm{p} S$-BSA diluted in PBS ( $\mathrm{pH}$ 6.8) with $10 \mathrm{ng} / \mathrm{ml}$ PDGF-BB in the lower chamber (25). The chambers were incubated for $4 \mathrm{~h}$ at $37^{\circ} \mathrm{C}$ under $5 \% \mathrm{CO}_{2}$ in air. The filter was removed, cells from the upper side of the chamber were gently scraped off, and the filter was fixed in $10 \%$ buffered formaldehyde, stained with $0.18 \%$ crystal violet, and examined microscopically $(\times 400)$. Cells were counted and migration was expressed as the mean number of cells that migrated per high power field.

Statistics. Data are presented as mean \pm SEM. Treatments were administered in a paired fashion with one femoral artery receiving $S$ nitrosated protein and the contralateral artery receiving the appropriate nonnitrosated control. $\mathrm{p} S$-NO-BSA bearing the two intermediate concentrations of displaceable NO was administered in paired fashion with pS-BSA, but not the highest or lowest concentration; this difference accounts for the difference in vessels used between treated and control groups described in the figure legends. SNP was given to a separate set of animals. Data were tested for normality using the Kolmogorov-Smirnov algorithm and for equal variance with the Levene median test. Normally distributed variables were compared using the paired $t$ test and nonnormally distributed variables were compared using the Wilcoxon signrank test or the Mann-Whitney rank-sum test. Nonpaired data were compared using an independent $t$ test. Statistical analysis of dose-response was performed by one-way ANOVA. Statistical significance was accepted if the null hypothesis was rejected with $P<0.05$.

\section{Results}

NO content of S-nitrosothiol species. Using total protein concentration of $755 \mu \mathrm{M}(49.2 \mathrm{mg} / \mathrm{ml})$, the synthesis of $S$-NOBSA resulted in a displaceable NO concentration of $230 \pm 60$ $\mu \mathrm{M}$, yielding a stoichiometry of $0.3 \pm 0.08 \mathrm{~mol} \mathrm{NO} / \mathrm{mol}$ albumin $(n=11)$. Polythiolation and S-nitrosation of BSA at a final protein concentration of $391 \mu \mathrm{M}(25.8 \mathrm{mg} / \mathrm{ml}, n=8)$ yielded a 5.9-fold increase in displaceable NO content with a maximum of $2,300 \mu \mathrm{M}$ displaceable $\mathrm{NO}$ or $5.9 \mathrm{~mol} \mathrm{NO} / \mathrm{mol}$ albumin. This stock solution was used with dilution in the experiments described below.

$S$-NO-BSA and pS-NO-BSA binding. The binding of locally and systemically delivered $\left[{ }^{125} \mathrm{I}\right]$-labeled $S$-NO-BSA and $\mathrm{p} S$ NO-BSA to balloon-injured rabbit femoral artery is shown in Fig. 1. Compared with systemic administration to an injured artery, local delivery of $\left[{ }^{125} \mathrm{I}\right]$-labeled $S$-NO-BSA to the site of injury was associated with a 26-fold increase in binding $\left(140.4 \pm 3.9 \times 10^{3} \mathrm{cpm} /\right.$ gram vs. $5.4 \pm 0.9 \times 10^{3} \mathrm{cpm} / \mathrm{gram}, n$ $=4 ; P=0.029)$. Endothelial denudation facilitated $S$-NOBSA binding as systemic administration of $\left[{ }^{125} \mathrm{I}\right]-S$-NO-BSA resulted in significantly greater deposition at the site of balloon injury compared with an uninjured control vessel both exposed
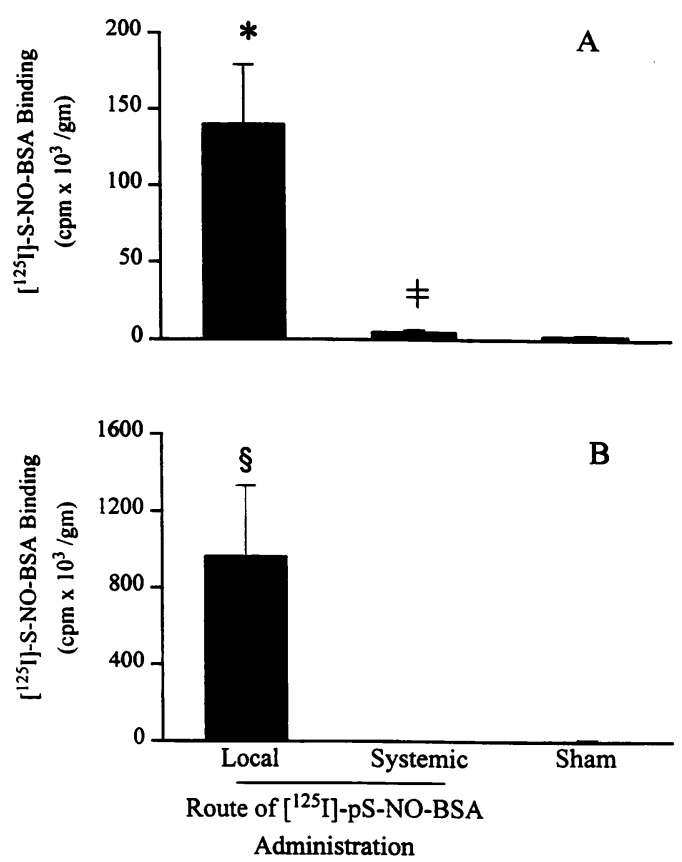

Figure 1. $\left[{ }^{125} \mathrm{I}\right]-S$-NO-BSA $(\mathrm{A})$ and $\left[{ }^{125} \mathrm{I}\right]-\mathrm{p} S$-NO-BSA $(B)$ binding as a function of the method of delivery. Rabbit femoral arteries were isolated and balloon-injured as described in Methods and the [ $\left.{ }^{125} \mathrm{I}\right]-$ labeled species applied either directly into the injured artery (Local) or injected intraarterially (Systemic). [ $\left.{ }^{125} \mathrm{I}\right]-S$-NO-BSA had a specific activity of $5.7 \times 10^{6} \mathrm{cpm} / \mu \mathrm{g}$ and $\mathrm{p} S$-NO-BSA had a specific activity of $18.2 \times 10^{6} \mathrm{cpm} / \mu \mathrm{g}$. [ $\left.{ }^{125} \mathrm{I}\right]-S$-NO-BSA or [ $\left.{ }^{125} \mathrm{I}\right]-\mathrm{p} S$-NO-BSA binding was determined by quantification of radioactivity after flow was reestablished for $15 \mathrm{~min}$. Nonspecific [ $\left.{ }^{125} \mathrm{I}\right]-S$-NO-BSA or [ $\left.{ }^{125} \mathrm{I}\right]-\mathrm{p} S$-NO-BSA binding (Sham) was determined from an uninjured carotid artery harvested simultaneously with the femoral arteries. Data are presented as mean \pm SEM per gram of wet tissue weight and are derived from four animals for [ $\left.{ }^{125} \mathrm{I}\right]-S$-NO-BSA and six animals for $\left[{ }^{125} \mathrm{I}\right]-\mathrm{p} S$-NO-BSA. $* P<0.05$, local vs. systemic delivery $\left[{ }^{125} \mathrm{I}\right]-S$-NO-BSA, ${ }^{\ddagger} P<0.05$, systemic injured vs. sham, $\left[{ }^{125} \mathrm{I}\right]-S$-NO-BSA, and ${ }^{8} P<0.05$ local vs. systemic delivery, $\left[{ }^{125} \mathrm{I}\right]-\mathrm{p} S$-NO-BSA.

to systemically delivered $\left[{ }^{125} \mathrm{I}\right]-S$-NO-BSA $\left(5.4 \pm 0.9 \times 10^{3}\right.$ $\mathrm{cpm} /$ gram vs. $\left.3.0 \pm 0.3 \times 10^{3} \mathrm{cpm} / \mathrm{gram}, n=4 ; P=0.038\right)$. Local delivery of $\left[{ }^{125} \mathrm{I}\right]$-labeled $\mathrm{p} S$-NO-BSA was also associated with increased binding compared with systemic delivery ( $976.1 \pm 365.6$ vs. $1.2 \pm 0.3 \mathrm{cpm} / \mathrm{gram}, n=6 ; P=0.045$ ). There was no significant difference in the binding of locally delivered $\left[{ }^{125} \mathrm{I}\right]-S$-NO-BSA and [ $\left.{ }^{125} \mathrm{I}\right]-\mathrm{p} S$-NO-BSA (0.054 vs. $0.055 \mu \mathrm{g} /$ gram, respectively).

pS-NO-BSA effect on platelet binding to injured vessel. Since platelet adhesion to the injured arterial surface is important in the proliferative response to injury, we investigated the effects of $\mathrm{p} S$-NO-BSA on platelet deposition after balloon injury, the results of which are shown in Fig. 2. The local administration of $\mathrm{p} S$-NO-BSA reduced the adhesion of [ ${ }^{111} \mathrm{In}$ ]labeled platelets to the injured vessels more than fourfold compared with control $\left(71.3 \pm 40.4 \times 10^{3} \mathrm{cpm} /\right.$ gram vs. $16.3 \pm 6.2$ $\times 10^{3} \mathrm{cpm} /$ gram, $\left.n=6, P<0.031\right)$.

$S-N O-B S A$ and $p S-N O-B S A$ effects on neointimal proliferation. Neointimal proliferation after local delivery of S-nitrosated proteins and appropriate controls was evaluated by comparing the lumen area, absolute neointimal area, and neointima/media 


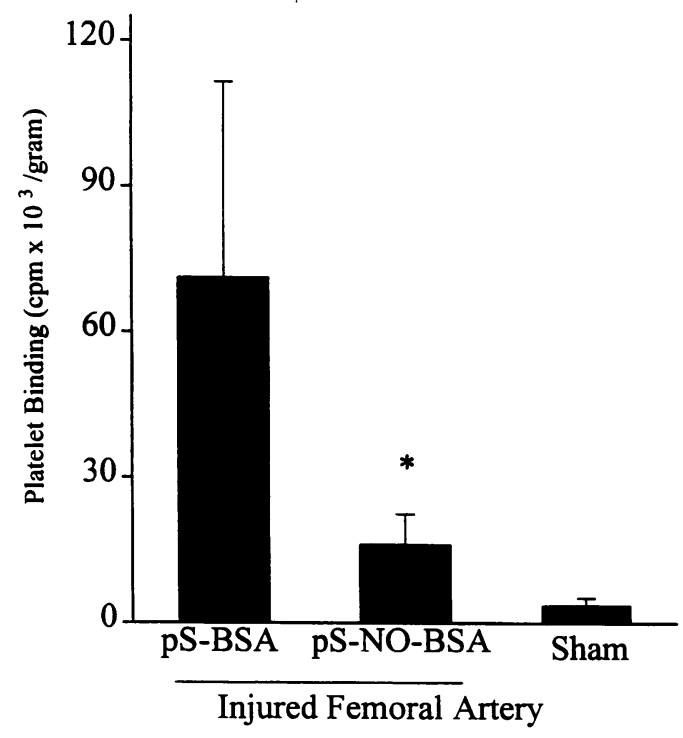

Figure 2. The effect of $\mathrm{p} S$-NO-BSA and $\mathrm{p} S$-BSA on ["1'In]-labeled platelet binding to injured rabbit femoral artery. Femoral arteries were isolated and balloon-injured as described in Methods. During paired local administration of $\mathrm{p} S$-NO-BSA and $\mathrm{p} S$-BSA, [ $\left.{ }^{111} \mathrm{In}\right]$-labeled platelets were administered intravenously and allowed to circulate after flow was reestablished in the treated arteries. [ $\left.{ }^{111} \mathrm{In}\right]$-Labeled platelet binding was determined by quantification of radioactivity after flow was reestablished for a period of $15 \mathrm{~min}$. Nonspecific [ ${ }^{111}$ In]-labeled platelet binding (Sham) was determined from uninjured carotid artery harvested with femoral arteries. Data presented are mean \pm SEM per gram of wet tissue weight and are derived from six animals. $* P<0.05, \mathrm{p} S$-BSA vs. pS-NO-BSA.

ratios, as shown in Fig. 3. Compared with BSA, the administration of $S$-NO-BSA did not significantly increase lumen area $\left(0.85 \pm 0.059 \times 10^{5} \mu \mathrm{m}^{2}\right.$ vs. $\left.1.47 \pm 0.5710^{5} \mu \mathrm{m}^{2}, n=15\right)$, reduce neointimal area $\left(2.54 \pm 0.33 \times 10^{5} \mu \mathrm{m}^{2}\right.$ vs. $2.54 \pm 0.33$ $\left.\times 10^{5} \mu \mathrm{m}^{2}, n=15\right)$, or reduce neointima/media ratio $(1.07 \pm 0.17$ vs. $0.72 \pm 0.084, n=15)$, although a trend was noted. By contrast, compared with $\mathrm{p} S$-BSA, the administration of $\mathrm{p} S$-NO-BSA with greater displaceable NO content maintained the lumen area $\left(0.31 \pm 0.061 \times 10^{5} \mu \mathrm{m}^{2}\right.$ vs. $0.86 \pm 0.12$ $\left.\times 10^{5} \mu \mathrm{m}^{2}, n=7, P=0.010\right)$, reduced neointimal area by $81 \%\left(2.24 \pm 0.33 \times 10^{5} \mu \mathrm{m}^{2}\right.$ vs. $0.41 \pm 0.11 \times 10^{5} \mu \mathrm{m}^{2}, n=7$, $P=0.022)$, and reduced the neointima/media ratio by $77 \%$ $(0.85 \pm 0.12$ vs. $0.20 \pm 0.066, n=7, P=0.025)$. The lumen area $\left(1.22 \pm 0.80 \times 10^{5} \mu \mathrm{m}^{2}, n=7\right)$, neointimal area $\left(0.23 \pm 0.07 \times 10^{5} \mu \mathrm{m}^{2}, n=7\right)$, and the neointima/media ratio $(0.12 \pm 0.041, n=7)$ in the sham-operated animals were comparable with those of the vessels treated with $\mathrm{p} S$-NO-BSA. Using a relatively high concentration of a conventional NO donor, SNP $(2,300 \mu \mathrm{M})$, we noted a trend toward inhibition of neointimal proliferation in luminal area $\left(1.13 \pm 0.091 \times 10^{5} \mu \mathrm{m}^{2}, n\right.$ $=5)$, neointimal area $\left(1.47 \pm 4.15 \times 10^{5} \mu \mathrm{m}^{2}, n=5, P\right.$ $=0.056)$, and the neointima/media ratio $(0.60 \pm 0.19, n=5, P$ $=0.11$ ) compared with control. Illustrative photomicrographs of vessels treated with S-nitrosated albumins are shown in Fig. 4.

Displaceable NO effect on neointimal proliferation. Since $S$-NO-BSA exhibited a trend toward inhibition and $\mathrm{p} S$-NOBSA clearly inhibited neointimal proliferation, we examined the relationship between the amount of displaceable NO and the extent of neointimal response after vascular injury; these results are presented in Fig. 5. A trend toward preservation of lumen area was noted with increasing concentrations of displaceable NO in the S-nitrosated albumin $(P=0.192)$. However, there was a significant inverse relationship between displaceable NO and neointimal proliferation as quantified by absolute neointimal area $(P=0.001)$ and the neointima/media area ratio $(P=0.001)$.

p-NO-BSA effects on cellular proliferation. Mouse monoclonal antibody staining against PCNA was used to assay the degree of S1-phase activity at $7 \mathrm{~d}$ after injury, the time point at which PCNA-positive cells are maximally present. At this time point, no difference in the percentage of proliferating cells was noted between vessels treated with p $S$-BSA $(30.1 \pm 5.9 \%$, $n=5)$ and vessels treated with p $S$-NO-BSA (37.8 $\pm 5.9 \%, n$ $=6$ ). Similarly, no significant difference was noted in the $\mathrm{S} 1$-phase activity of the $\mathrm{pS}$-NO-BSA-treated vessels compared with the $\mathrm{pS}$-BSA-treated controls (neointimal area: $0.124 \pm 0.06 \times 10^{5} \mu \mathrm{m}^{2}$ vs. $0258 \pm 0.19 \times 10^{5} \mu \mathrm{m}^{2}, n=5$, $P=0.54$, and neointima/media ratio: $0.32 \pm 0.005$ vs. $0.068 \pm 0.027, n=6, P=0.15$ ).

pS-NO-BSA-treated vessel effect on platelet cGMP and vessel $c G M P$. NO inhibits platelets and relaxes smooth muscle cells through a cGMP-mediated mechanism. Thus, we tested the ability of $\mathrm{p} S$-NO-BSA-treated vessels to increase platelet and vascular cGMP. Platelet cGMP was significantly increased after a 1-min exposure to $\mathrm{p} S$-NO-BSA-treated vessels compared with $\mathrm{p} S$-BSA controls $\left(19.9 \pm 3.3\right.$ vs. $4.11 \pm 0.9 \mathrm{pmol} / 10^{8}$ platelets, $n=14, P=0.001$ ); each vessel was washed three times with normal saline before incubation with platelets. In addition, vascular cGMP levels were also elevated after treatment with $\mathrm{p} S$-NO-BSA compared with $\mathrm{p} S$-BSA control $(0.253 \pm 0.092$ vs. $0.041 \pm 0.008 \mathrm{pmol} / \mathrm{mg}$ protein, $n=13, P$ $=0.002$ ), demonstrating a direct effect on vascular smooth muscle as well. The results are shown in Fig. 6.

VSMC migration. As VSMC migration to the site of injury may be important in the reparative and proliferative response of the vessel after injury, we examined the effect of $\mathrm{p} S$-NO-BSA on VSMC migration stimulated by a physiologically relevant agonist, PDGF-BB. p $S$-NO-BSA inhibited VSMC migration compared with $\mathrm{p} S$-BSA $(2.5 \pm 0.42$ vs. $14.2 \pm 3.65$ cells $/ \mathrm{high}$ power field, $n=6, P=0.002)$ and PBS controls (27.5 \pm 3.58 cells/high power field, $n=6, P=0.002$ ), as demonstrated in Fig. 7.

\section{Discussion}

We have demonstrated previously that NO combines with protein sulfhydryl groups in the presence of molecular oxygen to form stable, biologically active molecules with cGMP-dependent vasodilatory and antiplatelet properties, both in vitro and in vivo $(12,13)$. The data presented here demonstrate that serum albumin, after $S$-nitrosation, can bind avidly to ballooninjured femoral arteries and inhibit neointimal proliferation. This phenomenon is associated with diminished platelet deposition at the site of injury through a cGMP-dependent mechanism and elevation of the vessel cGMP. Moreover, the extent of inhibition of neointima formation is directly related to the quantity of displaceable NO carried by albumin.

The endothelium is essential for vascular integrity, control 

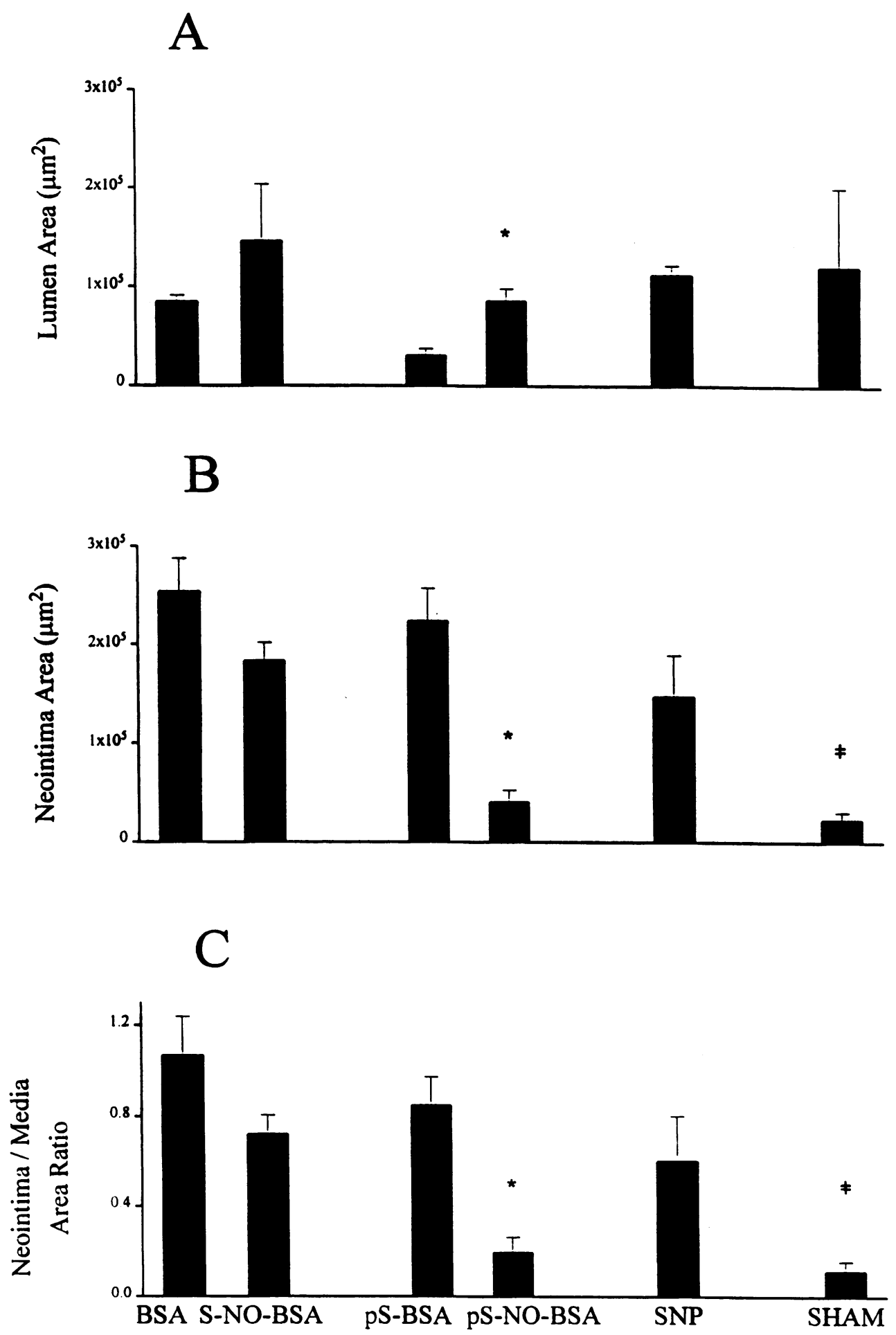

Figure 3. The effect of $S$-NO-BSA or $\mathrm{p} S$-NO-BSA and BSA or $\mathrm{p} S$ BSA on neointimal proliferation $14 \mathrm{~d}$ after balloon injury of rabbit femoral artery. Femoral arteries were isolated and balloon-injured as described in Methods. $\mathrm{p} S$-BSA and $\mathrm{p} S$-NO-BSA were applied in a paired fashion directly into the arterial lumen for $15 \mathrm{~min}$ and then blood flow was reestablished. After $14 \mathrm{~d}$, arteries were harvested, perfusion-fixed, stained, and subjected to morphometric analysis of the lumen, intimal, and medial areas. Neointimal proliferation is reported as the lumen area $(A)$, the absolute neointimal area $(B)$, and as a ratio of neointima/ media $(C)$ in three to six segments from each artery. Data are expressed as mean \pm SEM and are derived from 15 vessels in the BSA and $S$-NO-BSA groups, 11 vessels in the $\mathrm{p} S$-BSA group, 7 vessels in the $\mathrm{p} S$-NO-BSA and SHAM groups, and 5 in the SNP group. ${ }^{*} P<0.05, \mathrm{p} S$-NO-BSA vs. p $S$-BSA for all panels, ${ }^{\ddagger} P$ $<0.05$ SHAM vs. $\mathrm{p} S$-BSA for $B$ and $C$.

of thrombosis $(26,27)$, and the regulation of intimal growth (28). The endothelium serves these functions by the production of locally active effector molecules including EDRF, a compound that has been identified as NO or a closely related NOcontaining molecule. EDRF is responsible, in part, for many biologic actions via the activation of guanylyl cyclase, including relaxation of vascular smooth muscle $(3,29)$, inhibition of platelets (7), control of leukocyte adhesion to the subendothe- lium (30), modulation of vascular permeability (31), and, perhaps, local control of vascular smooth muscle growth. Since balloon angioplasty removes the endothelium from arterial smooth muscle, these endothelial functions are lost after the procedure. In particular, removal of the endothelium and damage to the smooth muscle cells are associated with intimal proliferation (32). The mechanism for this response is complex and involves platelet deposition and activation, cytokine elabora- 

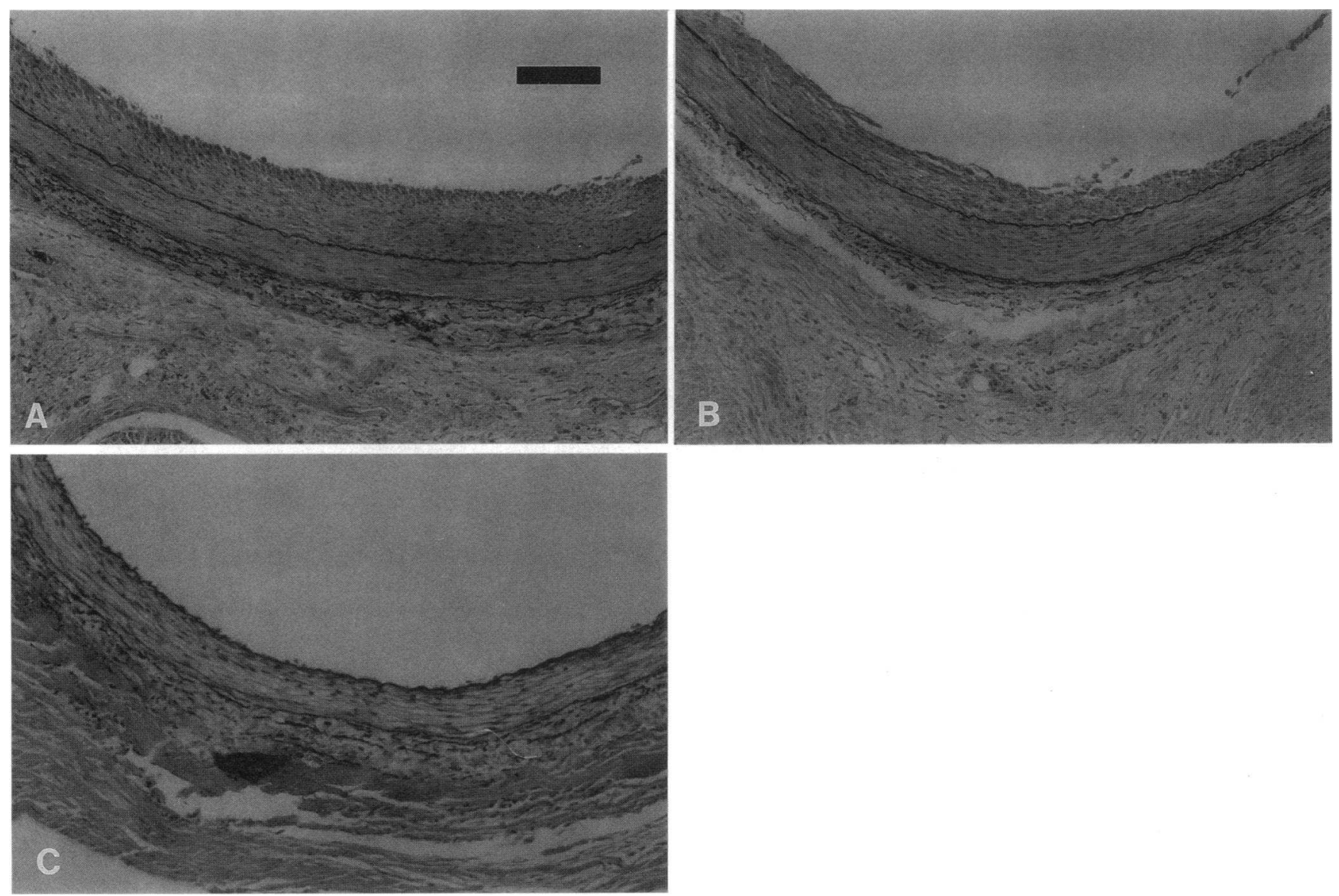

Figure 4. Illustrative photomicrographs of the effects of control and $S$-nitrosated serum albumin on neointimal proliferation. Femoral arteries were isolated and balloon-injured as described in Fig. 2. Vessels were exposed to three different agents differing in amount of displaceable NO: $(A)$ BSA alone, $(B) S$-NO-BSA containing $0.3 \pm 0.1 \mathrm{~mol}$ displaceable NO per mole albumin, or $(C)$ p $S$-NO-BSA containing $3.2 \pm 1.3$ mol displaceable NO per albumin molecule and flow was reestablished. After $14 \mathrm{~d}$, arteries were harvested, perfusion-fixed, paraffin-embedded, sectioned, and stained with Verhoeff's stain for elastic tissue. Bar, $100 \mu \mathrm{m}$ for all panels. $\times 10$.

tion, smooth muscle cell migration and proliferation, and extracellular matrix production. After balloon injury, the endothelium regenerates rapidly but is often dysfunctional and presumably is unable to maintain an adequate antithrombotic, vasodilating, and antiproliferative phenotype (16).

NO donors have been used with some success in the setting of balloon injury to produce decreases in intimal proliferation and in platelet deposition. In the porcine carotid model, Groves and colleagues (33) demonstrated reduced platelet adhesion and thrombus formation locally after systemic administration of SIN-1, a spontaneous NO donor and metabolite of molsidomine. These authors showed a 2.3-fold reduction in platelet deposition without any significant hemodynamic changes. Because administration of this agent was associated with an increase in template bleeding time and in platelet cGMP, it is possible that SIN-1 exerted its effects through systemic platelet inhibition. A preliminary report from the ACCORD trial also suggests that NO donors might be effective adjuncts for balloon angioplasty in humans (9). This multicenter study evaluated SIN-1 acutely and molsidomine chronically over 6 mo with diltiazem treatment as a control arm in patients undergoing balloon angioplasty. The loss index and binary restenosis rate were significantly improved in the NO treatment group, although the late loss was not significantly different between groups. Chronic supplementation with l-arginine, a precursor of endotheliumderived NO, has been shown to reduce intimal hyperplasia in rabbit thoracic aorta (34) and rat carotid artery (35). By contrast, administration of an inhibitor of NO synthase, $N^{\mathrm{G}}$-nitrol-arginine methyl ester, accelerated neointimal formation in the setting of balloon injury (36).

von der Leyen and colleagues (37) recently reported successful transfection of the constitutive endothelial-type NO synthase (eNOS) gene in a rat carotid injury model. In that preliminary study, eNOS incorporation and NO production were demonstrable $4 \mathrm{~d}$ after transfection, and neointimal proliferation was partially inhibited 2 wk after injury and transfection. In our study, $S$-nitrosated albumin was administered acutely, and,

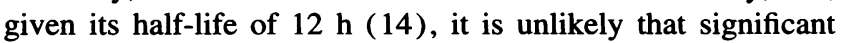
amounts of displaceable NO were still present $4 \mathrm{~d}$ after injury. The effectiveness of both early and late administration of NO suggests that NO may influence the complex response to injury by multiple mechanisms. In addition to modifying the development of platelet thrombus and the release of growth factors from platelets, local delivery of $S$-nitrosothiols could modulate gene transcription in VSMC (38) as well as smooth muscle metabolism after injury. In addition, by inducing VSMC cyto- 

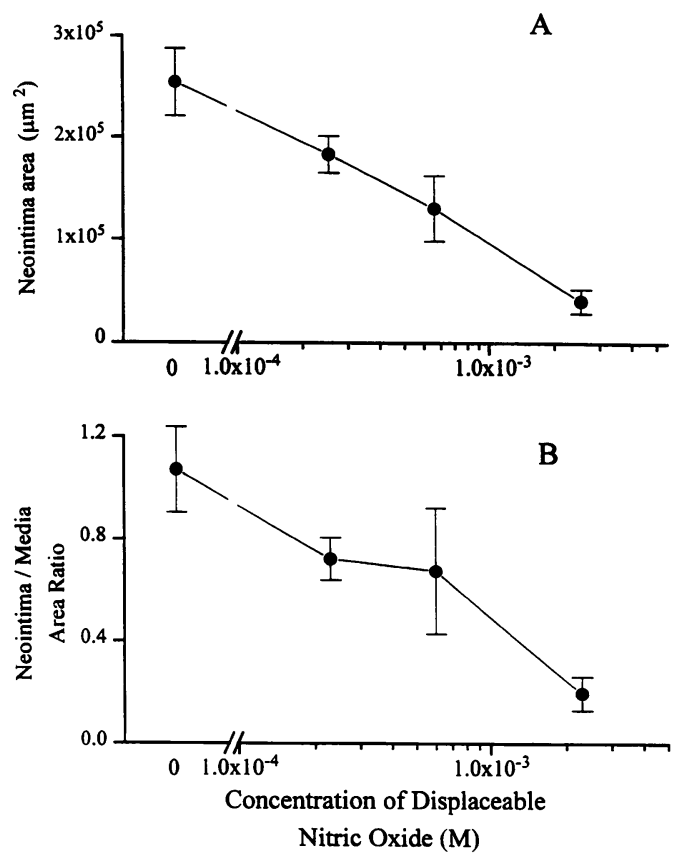

Figure 5. The relationship between neointimal proliferation and the quantity of displaceable NO in preparations of $S$-nitrosated albumin. Femoral arteries were isolated and balloon-injured as described in Fig. 3 . Vessels were exposed to different preparations of $S$-nitrosated albumin with different stoichiometric amounts of displaceable NO. After 14 $d$ vessels were harvested and analyzed as described in Fig. 3. Data are expressed as mean $\pm S E M$ and are derived from 4-15 animals in each group. $P=0.001$ for trend.

toxicity directly, NO may facilitate release of basic fibroblast growth factor from VSMC which, in turn, stimulates endothelial cell growth (39).

Our data demonstrate a profound limitation of neointimal proliferation after a single, local administration of a durable, potent $S$-nitrosothiol. Antiplatelet activity may explain these findings, in part, since we observed a fourfold reduction in platelet deposition to injured arterial segments after treatment with $\mathrm{p} S$-NO-BSA. Similarly, we also demonstrated direct platelet inhibition by the $\mathrm{p} S$-NO-BSA-treated vessel rings. Inhibition of platelet binding would result in many effects that are likely to reduce the proliferative response after injury. For example, platelet adhesion and aggregation are associated with the release of PDGF, basic fibroblast growth receptor, epidermal growth factor, and transforming growth factor- $\beta$, potent stimuli for smooth muscle cell proliferation and matrix production. $\mathrm{p} S$ NO-BSA could also exert its effect by modulating leukocytes through downregulated expression of either monocyte chemoattractant protein-1 (40) or adhesion molecules (41).

Moreover, we demonstrate that $S$-nitrosothiols can modulate VSMC migration. The role of cell migration in the formation of neointima in both animal studies and clinical restenosis is important, but the extent of its contribution to neointima formation is unclear (42). As NO is a multifunctional regulator of the vascular milieu, it is likely that multiple mechanisms exist whereby inhibition of neointima formation is achieved. We cannot exclude a direct inhibitory effect of NO on vascular smooth muscle gene expression, proliferation, or synthesis of extracellular matrix.
A

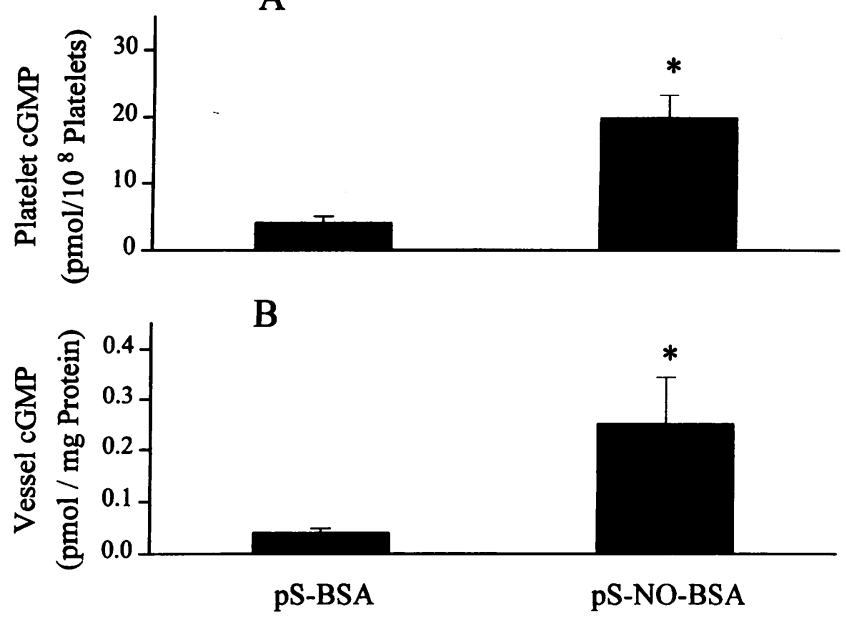

Figure 6. The effect of $\mathrm{p} S$-NO-BSA- and $\mathrm{p} S$-BSA-treated vessels on platelet $(A)$ and vessel $(B)$ cGMP. Rabbit femoral arteries were isolated and balloon-injured as described in Fig. 2. For platelet studies, paired local administration of $\mathrm{p} S$-NO-BSA and $\mathrm{p} S$-BSA to vessels for $15 \mathrm{~min}$ was followed by harvesting, rinsing, and dividing the segments into 2$\mathrm{mm}$ rings. The rings were then immersed in $100 \mu \mathrm{l}$ platelet-rich plasma containing $10 \mu \mathrm{M}$ 3-isobutyl-1-methylxanthine and were incubated for $1 \mathrm{~min}$ ex vivo. An equal volume of ice-cold $10 \%$ trichloroacetic acid was added to each aliquot and the sample was vortexed. Platelet cGMP assay was then performed as described in Methods. For vessel studies, rabbit femoral arteries were isolated, treated, and harvested as described for $A$. The rings were then immersed in $500 \mu$ l of ice-cold $10 \%$ trichloroacetic acid. The samples were sonicated and cGMP assays were performed as described in Methods. $* P<0.05$ for both panels.

The demonstration of PCNA-positive cells in vessels treated with $\mathrm{p} S$-NO-BSA compared with control vessels is intriguing. Hanke (43) demonstrated significant DNA synthesis in the neo-

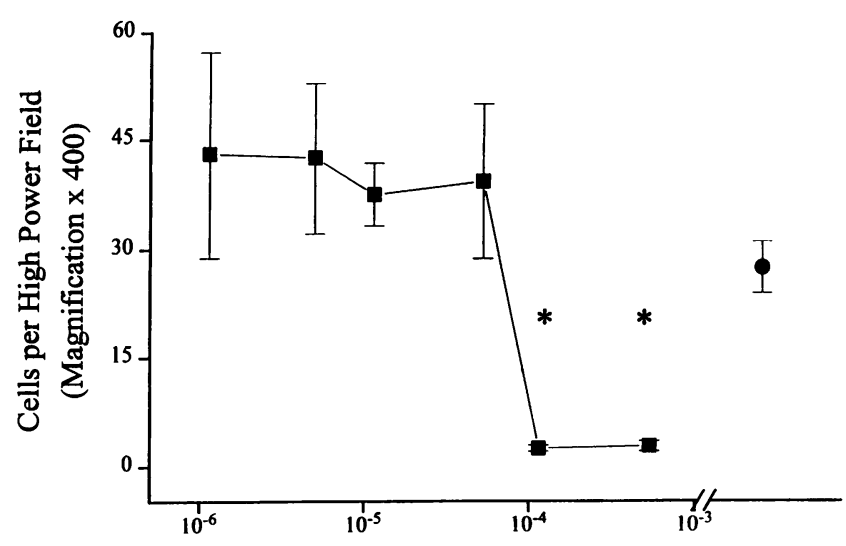

Concentration of Displaceable Nitric Oxide (M)

Figure 7. The effect of polythiolated $S$-nitroso-albumin on PDGF-BBstimulated VSMC migration. Cell migration studies were performed in a modified Boyden chamber seeded with 100,000 cells $/ \mathrm{ml}$. Cell migration was directed against PDGF-BB (10 $\mathrm{ng} / \mathrm{ml})$ in PBS control (filled circles) or in the presence of varying concentrations of $\mathrm{p} S$-NO-BSA (filled squares). Data are expressed as mean \pm SEM for three high power fields per chamber. All experiments were performed in duplicate. ${ }^{*} P$ $<0.05$ PBS vs. $\mathrm{p} S$-NO-BSA. 
intima and media of a rabbit carotid model using electrical stimulation. Maximal DNA synthesis occurred at $\sim 7 \mathrm{~d}$ (43) and lasted for at least $14 \mathrm{~d}$. Our observations suggest a mechanism other than the inhibition of local cell replication by which to explain the inhibition of neointimal proliferation in the rabbit injury model. We demonstrate a significant decrease in VSMC migration after exposure to $\mathrm{p} S$-NO-BSA which may, in part, explain these findings. Yet, given the complexity of the reparative process, other mechanisms could include transient inhibition of DNA synthesis, which is not evident on day 7 after injury; inhibition of extracellular matrix production; or inhibition of another factor( $s$ ) required for neointima formation.

These findings have several implications for the treatment of human disease. Mechanical removal of the endothelium abolishes the vasodilator responses to endothelium-dependent vasoactive stimuli, while leaving the vasoconstrictor effects of agonists to smooth muscle unopposed (1). This process occurs with balloon angioplasty especially at sites where platelet thrombus is noted $(44,45)$. Thus the strategy of local replacement of an important endothelial product as therapy for acute thrombotic phenomena and restenosis after angioplasty is suggested by our results.

In summary, our results demonstrate that a stable NO adduct of serum albumin binds avidly to balloon-injured subendothelium when delivered locally. Modified to carry multiple NO groups, $\mathrm{p} S$-NO-BSA markedly decreases neointimal proliferation after balloon injury. Local delivery of this molecule decreases platelet adhesion to the injured subendothelium and directly inhibits the platelet, interrupting a common pathway through which growth responses are initiated. This molecule markedly decreases VSMC migration, an important element in the reparative response to vessel injury. The implications of these findings suggest that local delivery of $S$-nitrosothiols may be an effective treatment for disease states marked by abnormal or absent endothelium, including restenosis after angioplasty.

\section{Acknowledgments}

The authors wish to thank Ms. Stephanie Francis, Ms. Kathleen Horten, Ms. Stephanie Tribuna, and Ms. Katherine Seropian for their expert technical assistance.

This work was supported by National Institutes of Health grants HL-48743, HL-47416, and HL-07064, a Veterans Administration Merit Review Award, and a grant from NitroMed, Inc. Joseph Vita is the recipient of a Clinical Investigator Award (K08HL02580), John Keaney is the recipient of a National Research Service Award (F32HL08635), and Joseph Loscalzo is the recipient of a Research Career Development Award (HL-022737) all from the National Institutes of Health.

\section{References}

1. Furchgott, R. F., and J. F. Zawadzki. 1980. The obligatory role of endothelial cells in the relaxation of arterial smooth muscle cell by acetylcholine. Nature (Lond.). 288:373-376.

2. Moncada, S., P. M. Palmer, and E. A. Higgs. 1991. Nitric oxide: physiology, pathophysiology and pharmacology. Pharmacol. Rev. 43:109-142.

3. Myers, P. R., R. L. Minor, Jr., R. Guerra, Jr., J. N. Bates, and D. G. Harrison. 1990. Vasorelaxant properties of the endothelium-derived relaxing factor more closely resembles $S$-nitrosocysteine than nitric oxide. Nature (Lond.). 345:161163.

4. Stamler, J., M. Mendelsohn, P. Amarante, D. Smick, N. Andon, D. F. Davies, J. P. Cooke, and J. Loscalzo. 1989. $N$-acetylcysteine potentiates platelet inhibition by endothelium-derived relaxing factor. Circ. Res. 65:789-795.

5. Scharfstein, J., J. F. Keaney, Jr., A. Slivka, G. Welch, J. A. Vita, J. Stamler, and J. Loscalzo. 1994. In vivo transfer of NO between a plasma protein-bound reservoir and low molecular weight thiols. J. Clin. Invest. 94:1432-1439.

6. Liu, M. W., G. S. Roubin, and S. B. King III. 1989. Restenosis after coronary angioplasty. Potential biologic determinants and role of intimal hyperplasia. Circulation. 79:1374-1387.

7. Ferns, G. A. A., E. W. Raines, K. H. Sprugel, A. S. Motani, M. A. Reidy, and R. Ross. 1991. Inhibition of neointimal smooth muscle accumulation after angioplasty by an antibody to PDGF. Science (Wash. DC). 253:1129-1132.

8. Vallance, P., J. Collier, and S. Moncada. 1989. Effects of endotheliumderived nitric oxide on peripheral arteriolar tone in man. Lancet. 2:997-1000.

9. Radomski, R. A., R. M. J. Palmer, and S. Moncada. 1987. Comparative physiology of endothelium-derived relaxing factor, nitric oxide and prostacyclin in platelets. Br. J. Pharmacol. 92:181-187.

10. Garg, U. C., and A. Hassid. 1986. Nitric oxide-generating vasodilators and 8-bromo-cyclic guanosine monophosphate inhibit mitogenesis and proliferation of cultured rat vascular smooth muscle cells. J. Clin. Invest. 83:1774-1777.

11. The ACCORD Study Investigators. 1994. Nitric oxide donors reduce restenosis after coronary angioplasty: the ACCORD study. J. Am. Coll. Cardiol. 23:59a. (Abstr.)

12. Stamler, J., D. I. Simon, J. A. Osborne, M. E. Mullins, O. Jaraki, T. Michel, D. Singel, and J. Loscalzo. 1992. S-nitrosylation of proteins with nitric oxide: synthesis and characterization of biologically active compounds. Proc. Natl. Acad. Sci. USA. 89:444-448.

13. Loscalzo, J. 1985. $N$-acetylcysteine potentiates inhibition of platelet aggregation by nitroglycerine. J. Clin. Invest. 76:703-708.

14. Keaney, J. F. Jr., D. I. Simon, J. Stamler, O. Jaraki, J. Scharfstein, J. A. Vita, and J. Loscalzo. 1993. NO forms an adduct with serum albumin that has endothelium-derived relaxing factor-like properties. J. Clin. Invest. 91:15821589.

15. Mendelsohn, M. E., S. O'Neill, D. George, and J. Loscalzo. 1990. Inhibition of fibrinogen binding to human platelets by $S$-nitroso- $N$-acetylcysteine. $J$. Biol. Chem. 265:19028-19034.

16. Weidinger, F. F. J. M. McLenachan, M. I. Cybulsky, J. B. Jordan, H. G. Rennke, N. K. Hollenberg, J. T. Fallon, P. Ganz, and J. P. Cooke. 1990. Persistent dysfunction of regenerated endothelium after balloon angioplasty of rabbit iliac artery. Circulation. 81:1667-1679.

17. Benesch, R., and R. E. Benesch. 1958. Thiolation of proteins. Proc. Natl. Acad. Sci. USA. 44:848-853.

18. Saville, B. 1958. A scheme for the colorimetric determination of microgram amounts of thiols. Analyst. 83:670- 672.

19. Lowry, O. H., N. J. Rosebrough, A. L. Farr, and R. J. Randall. 1951. Protein measurement with the Folin phenol reagent. J. Biol. Chem. 193:265-275.

20. Loscalzo, J., A. Inbal, and R. I. Handin. 1986. Von Willebrand protein facilitates platelet incorporation in polymerizing fibrin. J. Clin. Invest. 78:11121119.

21. Wistow, B. W., Z. D. Grossman, J. G. McAfee, G. Subramanian, R. W. Henderson, and M. L. Roskopf. 1978. Labeling of platelets with oxine complexes of Tc-99m and In-111. Part 1. In vitro studies and survival in the rabbit. J. Nucl. Med. 19:483-487.

22. Barone, L. M., B. Faris, S. D. Chipman, P. Toselli, B. W. Oakes, and C. Franzblau. 1985. Alteration of the extracellular matrix of smooth muscle cells by ascorbate treatment. Biochim. Biophys. Acta. 840:245-254.

23. Oakes, B. W., A. C. Batty, C. J. Handley, and L. B. Sandberg. 1982. The synthesis of elastin, collagen, and glycosaminoglycans by high density primary cultures of neonatal rat aortic smooth muscle. An ultrastructural and biochemical study. Eur. J. Cell Biol. 27:34-36.

24. Koyama, N., C. E. Hart, and A. W. Clowes. 1994. Different functions of the platelet-derived growth factor- $\alpha$ and $-\beta$ receptor for the migration and proliferation of baboon smooth muscle cells. Circ. Res. 75:682-691.

25. Koyama, N., N. Morisaki, Y. Saito, and S. Yoshida. 1992. Regulatory effects of platelet-derived growth factor AA homodimer on migration of vascular smooth muscle cells. J. Biol. Chem. 267:22806-22812.

26. Marcus, A. J., and L. B. Safier. 1993. Thromboregulation: multicellular modulation of platelet reactivity in hemostasis and thrombosis. FASEB (Fed. Am. Soc. Exp. Biol.) J. 7:516-522.

27. Yao, S. K., J. C. Ober, A. Krishnaswami, J. J. Ferguson, H. V. Anderson, P. Golino, L. M. Buja, and J. T. Willerson. 1992. Endogenous nitric oxide protects against platelet aggregation and cyclic flow variations in stenosed and endothelium-injured arteries. Circulation. 86:1302-1309.

28. Clowes, A. W., M. A. Reidy, and M. M. Clowes. 1983. Kinetics of cellular proliferation after arterial injury. Lab. Invest. 49:327-333.

29. Rees, D. D., R. M. Palmer, and S. Moncada. 1989. Role of endotheliumderived nitric oxide in the regulation of blood pressure. Proc. Natl. Acad. Sci. USA. 86:3375-3378.

30. Kubes, P., M. Suzuki, and D. N. Granger. 1991. Nitric oxide: an endogenous modulator of leukocyte adhesion. Proc. Natl. Acad. Sci. USA. 88:46514655. 
31. Kubes, P., and D. N. Granger. 1993. Nitric oxide modulates microvascular permeability. Am. J. Physiol. 262:H611-H615.

32. Reidy, M. A. 1985. Reassessment of endothelial injury and arterial lesion formation. Lab. Invest. 5:513-520.

33. Groves, P. H., M. J. Lewis, H. A. Cheadle, and W. J. Penny. 1993. SIN1 reduces platelet adhesion and platelet thrombus formation in a porcine model of balloon angioplasty. Circulation. 87:590-597.

34. McNamara, D. B., B. Bedi, H. Aurora, L. Tena, L. J. Ignarro, P. J. Kadowitz, and D. L. Akers. 1993. L-arginine inhibits balloon catheter-induced intimal hyperplasia. Biochem. Biophys. Res. Commun. 193:291-296.

35. Taguchi, J., A. Junichi, Y. Takuwa, and K. Kurokawa. 1993. L-arginine inhibits neointimal formation following balloon injury. Life Sci. 53:387-392.

36. Cayatte, A. J., J. J. Palocino, K. Horten, and R. A. Cohen. 1994. Chronic inhibition of nitric oxide production accelerates neointimal formation and impairs endothelial function in hypercholesterolemic rabbits. Arterioscler. Thromb. 14:753-759.

37. von der Leyen, H., G. H. Gibbons, R. Morishita, N. P. Lewis, F. Diet, J. P. Cooke, L. Zhang, Y. Yaneda, and V. Dzau. 1994. Overexpression of constitutive endothelial-type nitric oxide synthase as an in vivo gene transfer approach to prevent neointima formation after vascular injury. Clin. Res. 42:180a. (Abstr.)

38. Taubman, M. B. 1993. Gene induction in vessel wall injury. Thromb. Haemostasis. 70:180-183.
39. Fukuo, K., T. Inoue, S. Morimoto, T. Nakahashi, O. Yasuda, K. Stoichi, R. Sasada, and T. Ogihara. 1995. Nitric oxide mediates cytotoxicity and basic fibroblast growth factor releases in cultured vascular smooth muscle cells. J. Clin. Invest. 95:669-676.

40. Zeiher, A. M., B. Schray-Utz, and R. Busse. 1993. Nitric oxide modulates monocyte chemoattractant protein 1 in human endothelial cells: implications for the pathogenesis of atherosclerosis. Circulation. 88:I-367.

41. Lefer, D. J., D. A. Klunk, G. A. Lutty, C. Merges, R. P. Schleimer, B. S. Bochner, and J. L. Sweier. 1993. Nitric oxide donors reduce basal ICAM-1 expression on human aortic endothelial cells. Circulation. 88:I-565.

42. Casscells, W. 1992. Migration of smooth muscle and endothelial cells. Circulation. 86:723-729.

43. Hanke, H., T. Strohschneider, M. Oberhoff, E. Betz, and K. R. Karsch. 1990. Time course of smooth muscle cell proliferation in the intima and media of arteries following experimental angioplasty. Circ. Res. 67:651-659.

44. Uchida, Y., K. Hasegawa, K. Kawamura, and I. Shibuya. 1989. Angioscopic observations of the coronary luminal changes induced by percutaneous transluminal coronary angioplasty. Am. Heart J. 117:769-776.

45. Steele, P. M., J. H. Chesebro, A. W. Stanson, J. R. Holmes, Jr., M. K. Dewanjee, L. Badimon, and V. Fuster. 1985. Balloon angioplasty: natural history of the pathophysiological response to injury in a pig model. Circ. Res. 57:105112. 